\title{
MORAE IN ESTONIAN. A REPLY TO NATALJA KUZNETSOVA'S PAPER 'ESTONIAN WORD PROSODY ON THE PROCRUSTEAN BED OF MORAE"
}

\author{
Külli Prillop \\ Tartu Ülikool
}

\begin{abstract}
This reply to Natalja Kuznetsova highlights many questionable interpretations and outcomes, ten serious errors and five minor inaccuracies in her polemical paper "Estonian word prosody on the Procrustean bed of morae" (2018). The proposed list of errors includes misinterpretations of Estonian language data, faulty citations and biased conclusions.
\end{abstract}

Keywords: structural functional phonology, autosegmental phonology, word prosody, mora, quantity, overlength, Estonian

DOI: https://doi.org/10.12697/jeful.2019.10.2.08

\section{Introduction}

Estonian is widely known for its three degrees of contrastive quantity (see Asu and Teras 2009). The Estonian quantity system has inspired many linguists to develop and test new phonological theories. Natalja Kuznetsova (2018) argues for a structural functional framework, which shifts the boundaries of phonology and morphology: what is usually described as Estonian morphology is treated by Kuznetsova as phonology, and traditional phonological questions about the Estonian quantity system are left unanswered. Such an approach is not a problem in itself. Yet unfortunately, instead of truly developing and testing the idea, Kuznetsova focuses on criticizing earlier phonological models of Estonian quantity and the concept of the mora.

After providing some background information about Estonian phonology and morphonology ( $\$ 2)$, I analyze Kuznetsova's functional structural account and proposed formalism ( $(3)$. In the following sections ( $\S 4-8)$, I will present a non-exhaustive list of errors detected in Kuznetsova's paper, starting with the most egregious ones. 


\section{Background}

2.1. In Estonian, quantity is an underlying property of lexemes. Generally, it is not predictable from the segmental structure of the word. For example: ${ }^{1}$

\begin{tabular}{|c|c|c|}
\hline first quantity (Q1) & $\begin{array}{l}\text { kalu [kalu'] } \\
\text { 'fish, part. pl.', }\end{array}$ & $\begin{array}{l}\text { kala }[\mathrm{kala} \text { '] } \\
\text { 'fish', }\end{array}$ \\
\hline second quantity (Q2) & $\begin{array}{l}\text { kaalu }[\mathrm{ka}: \mathrm{lu}] \\
\text { 'scales, gen. sg.', }\end{array}$ & $\begin{array}{l}\text { kalla [kalla] } \\
\text { 'calla lily', }\end{array}$ \\
\hline third quantity (Q3) & $\begin{array}{l}\text { kaalu }[\mathrm{ka}: \mathrm{lu}] \\
\text { 'scales, part. sg,', }\end{array}$ & $\begin{array}{l}\text { kalla }[\mathrm{kal}: \mathrm{la}] \\
\text { 'pour, imp. 2nd sg.' }\end{array}$ \\
\hline
\end{tabular}

Estonian nouns can be organized into three basic declensions according to their quantity alternation patterns; see Table 1. A complete morphological classification also takes into account systematic qualitative alternations, syllable count, allomorphs of inflectional suffixes, and so on (e.g., Peebo 1997 and the traditional inflections -7 for nouns, 4 for verbs - described therein).

Table 1. Example of basic accent alternation patterns in Estonian (gray background: Q3, white background: Q2).

\begin{tabular}{|c|c|c|c|c|c|c|}
\hline & \multicolumn{3}{|c|}{$\begin{array}{l}\text { I. } \\
\text { nom. sg. Q3, } \\
\text { gen. sg. Q2 }\end{array}$} & \multirow{2}{*}{$\begin{array}{l}\text { II. } \\
\text { nom. sg. Q2, } \\
\text { gen. sg. Q3 } \\
\text { 'turn' }\end{array}$} & \multicolumn{2}{|c|}{$\begin{array}{c}\text { III. } \\
\text { Invariant quantity }\end{array}$} \\
\hline & 'salt' & 'hole' & 'island' & & 'honest' & 'lyre' \\
\hline nom. sg. & sool & $a u k$ & saar & pööre & aus & lüüra \\
\hline gen. sg. & soola & augu & saare & pöörde & ausa & lüüra \\
\hline part. sg. & soola & $a u k u$ & saar $+\boldsymbol{t}$ & pööre $+\boldsymbol{t}$ & $a u s a+t$ & lüüra $+\boldsymbol{t}$ \\
\hline gen. pl. & soola + de & $a u k u+d e$ & saar + te & pööre+te & ausa + te & lüüra+de \\
\hline part. pl. & sooli & auke & saari & pöörde $+\boldsymbol{i d}$ & ausa $+\boldsymbol{i d}$ & lüüra+sid \\
\hline
\end{tabular}

1 Example words are transcribed using Estonian IPA (see Asu and Teras 2009). Still, when representing structure (in the figures), I will transcribe geminates as $\mathrm{C}$, , not CC (e.g. $[\mathrm{kalla}]=[\mathrm{kal}: \mathrm{a}],[\mathrm{ka}: \mathrm{rtte}]=[\mathrm{ka}: \mathrm{rt}: \mathrm{e}])$, because Estonian geminates are structurally ambisyllabic consonants rather than sequences of identical consonants. 
2.2. There are basically two competing phonological approaches to modelling Estonian quantity. Some authors argue that Q2 and Q3 are specific accents on long syllables. Q1 is then just a CV-syllable ${ }^{2}$ without any accent (e.g., Hint 1986). According to a slightly modified version of this approach, Q2 is an ordinary long syllable but Q3 syllables reveal a property called 'prosodical quantity' (Hint 1997: 133); see Fig. 1. Very similar is also the view that segmentally long syllables (CVC, CVV, CVVC, etc.) may be light (monomoraic) or heavy (bimoraic) by weight (Ehala 2003: 69; also Viitso 2003: 11, although he does not use moraic theory).

Others (e.g. Prince 1980, Kager 1996, Prillop 2013) treat Q3 as a monosyllabic foot; see Fig. 2. Only a heavy syllable can form a foot by itself; feet are maximally disyllabic and syllables may be unparsed by feet (or feet may be recursive).

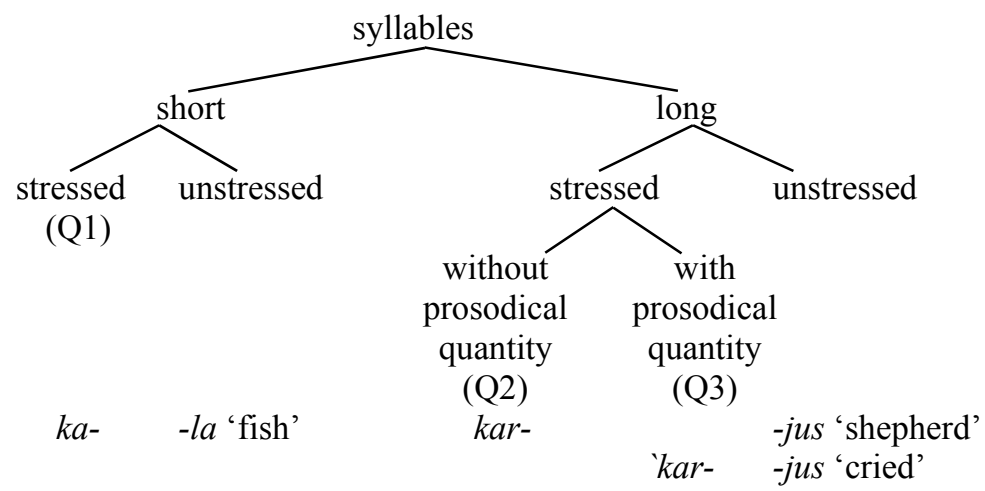

Figure 1. Types of Estonian syllables according to Hint (1997: 133, cf. Hint 1986: 435, 440).

$2 \mathrm{C}$ - consonant, $\mathrm{V}$ - vowel; later in the text also $\mathrm{X}$ - any segment, $\mathrm{G}$ - geminate consonant 

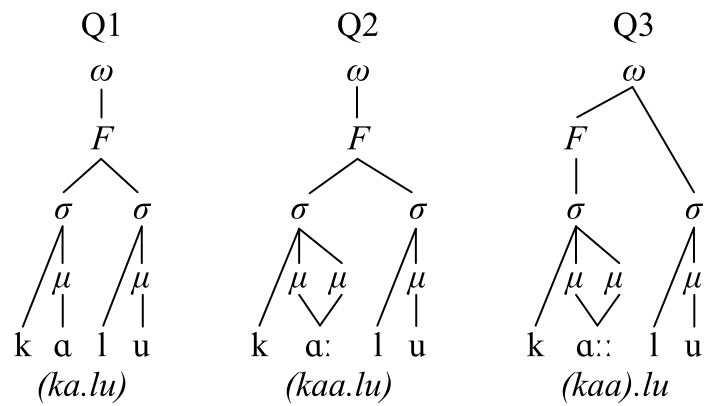

Figure 2. Estonian quantity degrees according to Prillop (2013, $2015,2018 \mathrm{a}, \mathrm{b}) .^{3}$

If we define Q3 as a monosyllabic foot, we can explain Estonian syllable types as it is shown in Fig. 3 ( $c f$. Fig. 1).

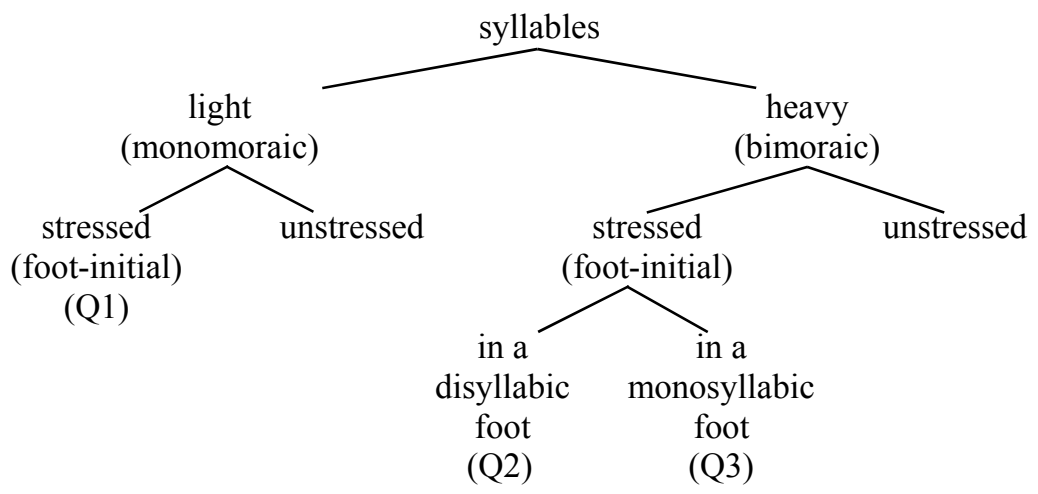

Figure 3. "Types" of Estonian syllables according to Prillop (2013, a.o.).

2.3. Treating $\mathrm{Q} 3$ as a monosyllabic foot explains an interesting feature of the Estonian stress system (see also $\$ 3.4$ and §7.1). Generally, primary stress falls on the first syllable and every odd syllable bears secondary stress (except word-finally). Heavy syllables and many suffixes (-line, -lik, etc.) can disrupt the binary stress placement algorithm so that foot lapses occur; for example (soo.mu).se.(li.ne) 'scaly', (e.se).

$3 \omega$-prosodic word, $F$ - foot, $\sigma$-syllable, $\mu$-mora. Brackets indicate foot boundaries; dots represent syllable boundaries. 
me.(li.ne) 'objective' or (ka.va).la.(ma[t].te) 'clever, gen. pl.'. In Q1 and Q2 words, secondary stress never falls on the second syllable. Obviously, whenever secondary stress is placed on the second syllable, the first syllable must form a monosyllabic foot (Q3) and therefore cannot be Q1 or Q2. Secondary stress after a monosyllabic foot is acceptable; for example, (ea).(li.ne) 'age-specific' or (kau).(ge[t].te) 'far, gen. pl.'. However, lapses are also possible, as in Q1 and Q2 words (see Table 2); for example, (pöör).de.(li.ne) 'turning'. To avoid stress clash, even two unparsed syllables are predicted word-finally; for example, (kau).ge.le. In Q1 and Q2 words, stress clash is impossible, as their second syllable is unstressed by definition and, therefore, a sequence of two unparsed syllables is illicit as well; for example, (ka.va).(la.ma) 'clever, comp. gen. sg.', never *(ka.va).la.ma.

Table 2. Estonian stress system basics

\begin{tabular}{ll|c|c}
\hline & \multicolumn{2}{c}{ Q1, Q2 } & \multicolumn{2}{c}{ Q3 } \\
\cline { 2 - 4 } & \multicolumn{2}{c}{ No clash } & Clash \\
\hline Without lapse & (ka.va).(la[t].te).le & - & (kau).(ge[t].te).le \\
With lapse & (ka.va).la.(ma[t].te) & (kau).ge.(ma[t].te) & - \\
\hline
\end{tabular}

2.4. The idea that Q3 forms a monosyllabic foot was suggested by Alan Prince (1980). Prince further observed that the prolonged duration of the final segment in a Q3 syllable (= Q3 foot) results from footfinal lengthening in the same way as the prolonged duration of the final vowel in a Q1 foot results from foot-final lengthening. Prillop (2013: 19) added that the syllable that follows a monosyllabic foot is normally unparsed, which may explain the reduction of the unstressed vowel in Q3 (see also §6). In those models that treat Q3 and Q2 as specific accents, foot-final lengthening can be explained by foot isochrony.

2.5. If Q2 and Q3 are features of syllables as a whole, it is difficult to define which segments in a Q3 syllable have increased duration. Several rules might be stated, such as "if a syllable contains a sequence of two vowels, the last vowel in the sequence lengthens in Q3," "if a

4 Orthographic $t$ is pronounced as an ambisyllabic consonant (geminate); thus, kavalamate $=[$ 'ka.va.la., mat.te]. 
syllable contains a sequence of two vowels followed by a sequence of two obstruents, the obstruents lengthen in Q3," "if a syllable contains a vowel followed by a sequence of two sonorants, the first sonorant lengthens in Q3," etc. (cf. Hint 2001: 324-331). In moraic accounts, we can simply say that the foot-final mora lengthens (Fig. 4). If the final mora is shared between segments (see also the discussion in §5.5), the last segment seems to be most prone to lengthening, see Table 3.

Long nucleus, Short nucleus, Long nucleus, short coda long coda long coda
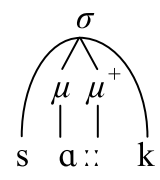
saag 'saw'

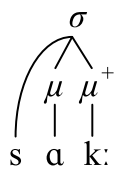
sakk 'tab' $\mathrm{k}$ u r: $\mathrm{k}$ $\mathrm{k}$ e 1: kurg 'crane' kell 'clock'

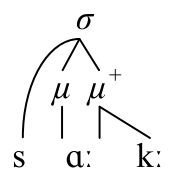

saak 'crop' k u r k:

1 a $\mathrm{u}: \mathrm{t}$ laud 'table' $\mathrm{t}$ o 1: $\mathrm{m}$ tolm 'dust' 1 a u: 1 laul 'song' k e:: 1 keel 'language'

+ syllable appendices
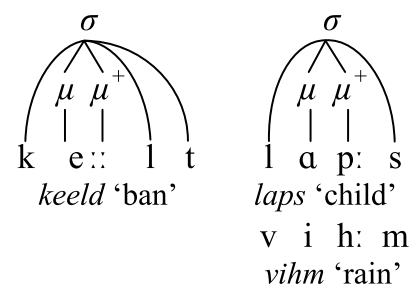

Figure 4. Examples of final mora lengthening (marked as $\mu^{+}$) in monosyllabic words. 
Table 3. Durations of the first syllable vowel and following consonant in Q2 and Q3 words (data from Eek and Meister 2003: 905).

\begin{tabular}{|c|c|c|c|c|c|c|c|c|}
\hline & & & \multicolumn{2}{|c|}{ Segment duration (ms) } & \multicolumn{2}{|c|}{ Q3 : Q2 } & \multicolumn{2}{|c|}{$S D$} \\
\hline & & & {$[a]$} & {$[\mathrm{t}]$} & [a] & {$[\mathrm{t}]$} & [a] & {$[\mathrm{t}]$} \\
\hline Q2 & saada & $\underbrace{\mu \mu}_{[\mathrm{sa}: \mathrm{ta}]}$ & 254 & 88 & \multirow{2}{*}{1.46} & \multirow{2}{*}{1.02} & 39.2 & 10.5 \\
\hline Q3 & saada & 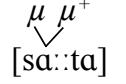 & 371 & 90 & & & 56.8 & 11.1 \\
\hline Q2 & kata & $\begin{array}{c}\mu \mu \\
\mid \mathrm{katta}] \\
\end{array}$ & 130 & 227 & \multirow{2}{*}{0.98} & \multirow{2}{*}{1.73} & 19.9 & 48.5 \\
\hline Q3 & katta & $\begin{array}{c}\mu \mu^{+} \\
\mid \text {kat:ta] } \\
\text { [kat }\end{array}$ & 128 & 393 & & & 15.3 & 60.3 \\
\hline Q2 & saate & [sa:tte] & 241 & 217 & \multirow{2}{*}{1.14} & \multirow{2}{*}{1.26} & 42.4 & 36.7 \\
\hline Q3 & saata & [sa:t:ta] & 275 & 273 & & & 41.6 & 43.1 \\
\hline
\end{tabular}

Underlyingly, vowels, fortis obstruents and geminate consonants are moraic. The surface structures shown in Fig. 4 are created following a four-step algorithm; see Fig. 5 (examples of polysyllabic words will be present in the following sections):

(1) Connect vowels (with their morae) to higher level nodes (syllable, foot, prosodic word). Adjacent vowels belong to the same syllable.

(2) Add second mora to every monomoraic foot. The mora (if not yet connected) will be connected to the segment following the moraic vowel.

(3) Connect freestanding consonants (with their morae) to syllable nodes. Syllables have onsets, if possible. Onsets are not complex (except word-initially). ${ }^{5}$

(4) In a trimoraic syllable, coalesce the second and the third mora ${ }^{6}$

5 The universal phonological constraints ONSET, NoCODA, and NoComPLEX ensure correct syllabification.

6 Mora sharing is the universal repair for trimoraic syllables (see Prillop 2018c: 445-451). Whether or not a mora can be shared between three segments, is still unclear. Investigating Estonian structures like kaart would therefore be important for universal phonological theory. Unfortunately, we do not have phonetic studies concerning such complex structures. 
158 Külli Prillop

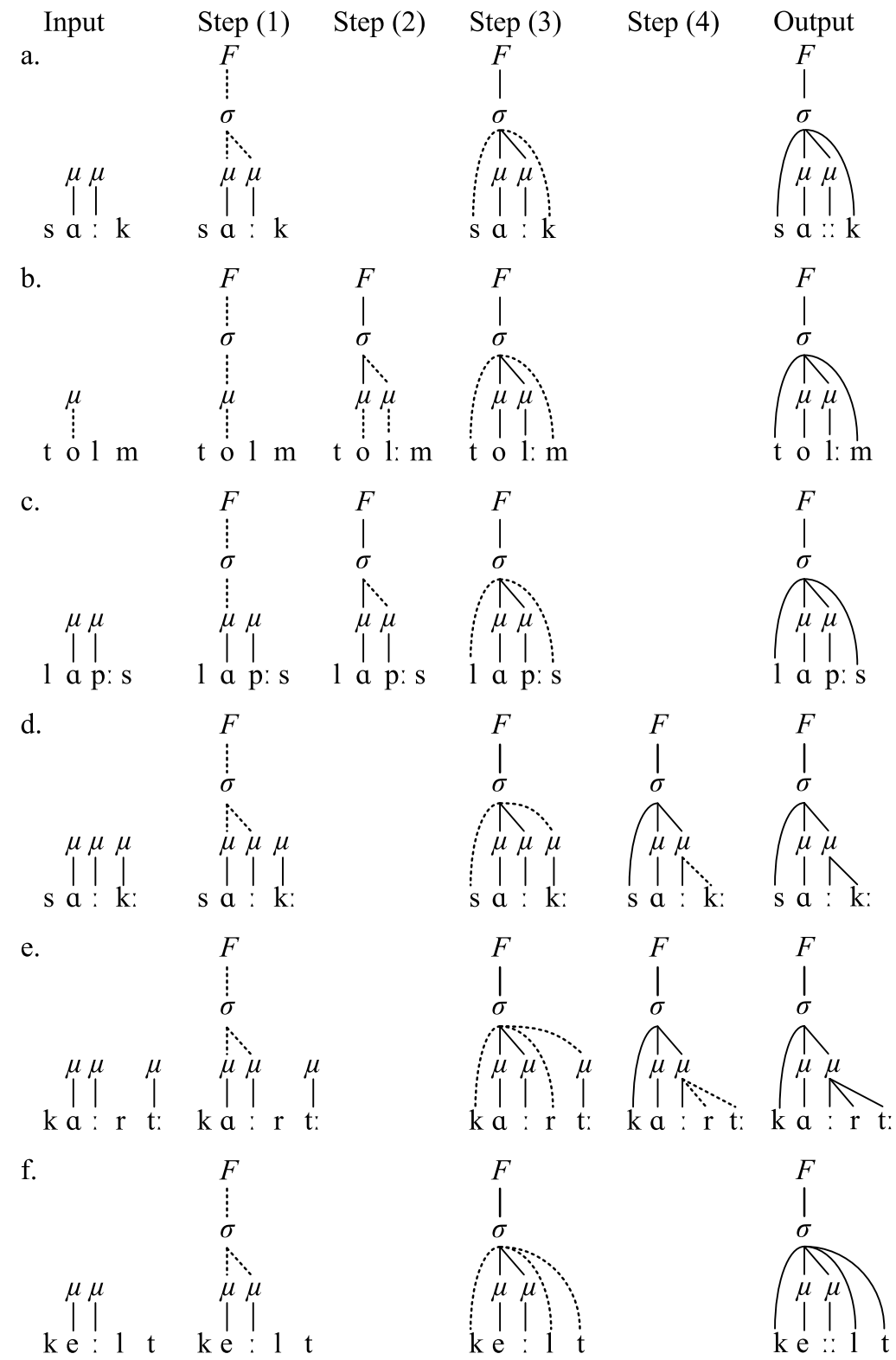

Figure 5. Building prosodic structure.

Here, for the sake of simplicity, I will present all such structures with three segments associated to one mora. Other possibilities and discussion can be found in Prillop (2013: 25, 2015: 188, 2018a: 360, 2018b, §5.5). 
2.6. The historical development of the Estonian language also seems to support the view that Q3 is a monosyllabic foot. Many Old Estonian word forms had a long vowel in the second syllable. Today, such words are in Q3. Prillop (2018a: 353-354) argues that long vowels attracted stress. Secondary stress on the second syllable means that the first syllable forms a monosyllabic (= Q3 now) foot. For example, pööre 'turn' is reconstructed as *pöortek. In the genitive, the case ending - $n$ was added, with an epenthetic vowel inserted between $k$ and $n$ : *öörteken. Intervocalic $* k$ weakened and dropped out, resulting in long $e$ in the second syllable, which was interpreted as stressed: *(pöör).(teen). Later, such long vowels became shortened and the secondary stress disappeared: (pöör).te. The first foot remained monosyllabic because, in many lexemes, the contrast between structures (CVX).CV and (CVX. $\mathrm{CV}$ ) helped to differentiate case forms; for example, in disyllabic vocalic stems: part. sg. *soola + ta $>$ *(soo).(laa) $>$ (soo).la; gen. sg. *soola $+n>$ $*$ (soo.lan) $>$ (soo.la). Of course, secondary stress on long vowels in Old Estonian is just a hypothesis. However, Prillop (2018b: 438) gives additional examples of the developmental paths of Q2 and Q3 in different structures:

Development of Q2

*(ham. ̌pas) > (ham.mas) 'tooth'

*(sil.män) > (sil.ma) 'eye, gen. sg.'

*(tüt.tür $)>$ (tüt.tar) 'daughter' (orthographic tütar)

Development of Q3

*(ham.pa).(hi.ta) >*(ham).(pai.ta) > (ham).(baid) 'tooth, part. pl.'

*(sil.mä). $\ddot{t a}>$ (sil).(mää) > (sil).ma 'eye, part. sg.'

*(tüt.tü).ren > (tüt).tə.ren > (tüt).re 'daughter, gen. sg.'

*(tu. a al).len >> (tu.a).le > (toa).le 'room, all. sg.'

2.7. In Estonian morphology, Q1/Q2 and Q3 can function as morphemes. For example, in lexemes like silm or sool where quantity distinguishes the gen. sg. and part. sg. forms, no segmental morpheme is added to the stem. In other case forms, inflectional endings are added but the stem must retain the correct quantity degree, which is defined by the declension, not by the case ending; for example, Q3 (soo).la. $+d e$, not*(soo.la).+de, but Q2 (lüü.ra). +de, not*(lüü).ra. +de (see Table 1). 
In Prillop's model (2018b: 440-445), Q1 and Q2 stem allomorphs must have the foot structure shown in Fig. 6a, and Q3 allomorphs the foot structure shown in Fig. $6 \mathrm{~b}$ (monosyllabic foot).

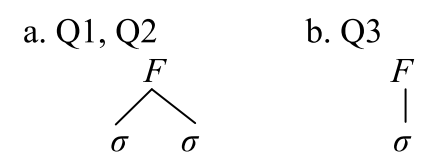

Figure 6. Lexically predefined structures for Q1/Q2 and Q3 allomorphs (Prillop 2018b: 440 Fig. 4).

To generate an output (surface) form, the underlying segmental structure of the lexeme, inflectional endings (if any), and the proper structure from Fig. 6 are assembled. As an example, Prillop (2018b: 441-442) explains the lenis-fortis alternation in lexemes like gen. sg. ladva [latva], part. sg. latva [lat:va] 'tree-top'. According to Prillop (2018a: 357-360), a fortis is a moraic stop, a lenis a nonmoraic stop. Normally, segments do not acquire morae ${ }^{7}$ nor lose their associations to morae during the output generation process. Therefore, /latva/ $\rightarrow$ [latva] is generated with a monomoraic initial syllable; see Fig. 7. A mora must be added only if a Q3 monosyllabic foot has to be built but the syllable is underlyingly monomoraic, as in the case of /latva/ $\rightarrow$ Q3 [lat:va], see Fig. 8. (More examples of other types of lexemes, including those with lexically bimoraic first syllables, are given in Prillop 2018b: 442-444.)

7 Syllable-final underlyingly nonmoraic sonorants and /s/ still may be variably moraic in output forms; see the discussion and data in Prillop 2018b: 439. 
Input

(1) Connect vowels to higher level nodes (connect input structures)
(3) Connect consonants to syllable nodes

Prosodic structure

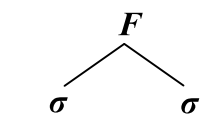

Segmental structure
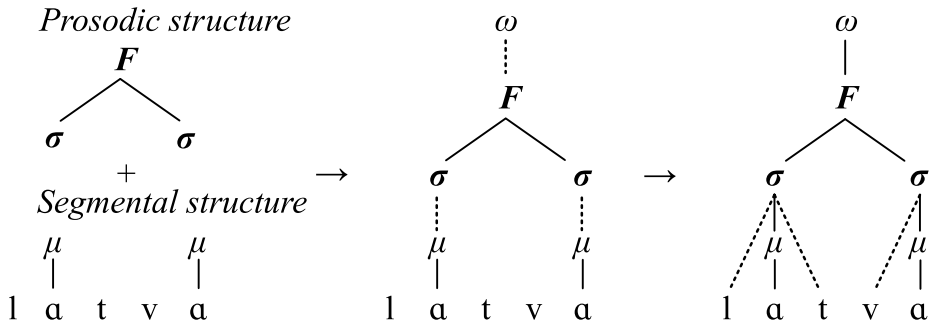

Figure 7. Generating ladva (cf. Fig. 5).

$$
\text { Input }
$$

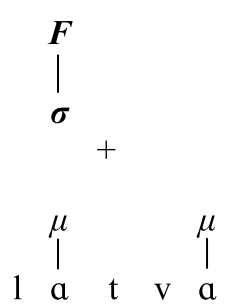

(1) Connect vowels

(2) Add second $\mu$
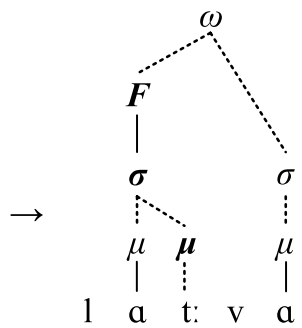

(3) Connect consonants

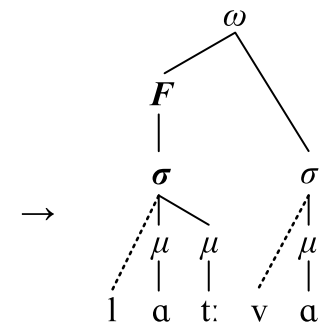

Figure 8. Generating latva (cf. Fig. 5).

Kuznetsova (2018) develops further the idea that Q1/Q2 and Q3 are specific accents. She denies morae as syllable constituents or as something that defines segmental length.

\section{Kuznetsova's formalism compared to the moraic model}

3.1. In the abstract of her paper, Kuznetsova promises to advance "a formal morphonological algorithm of calculating Estonian foot accents, which also shows the place of the syllable weight contrast."

8 In Kuznetsova (2018), heavy accent means third quantity (Q3); it is indicated by ` before the accented foot. Light accent means second quantity (Q2) or first quantity (Q1), indicated by '. Hereinafter in my reply I will use the same terms and notations as Kuznetsova (where possible). 
In fact, she presents mainly examples, not a formal algorithm. In its current form, I think it raises more questions than it answers. I will point out some of the questions.

Kuznetsova (2018: 231) treats Estonian accents as autosegmental units: "Accents are distinctive word-prosodic units, such as tones, and should rather be represented autosegmentally." The domain of accent is the foot, the bearer of accent is the foot nucleus, and the functional basis of accent is the morpheme (ibid.: 230). The foot nucleus is defined as "a prosodically active sequence from the first syllable vowel throughout the second syllable vowel" (ibid.: 216), while accent bearer is defined as the "minimal segmental structure which has to be present to make its realisation possible" (ibid.: 230). The foot itself in Kuznetsova's account is not a structural unit (ibid.: 216, fn. 1).

Kuznetsova's algorithm (2018: 234-237) is about calculating accents and their positions. The algorithm uses both phonological and morphological information. First the phonological structure and morphological structure are analyzed separately; then, to obtain the accent, the phonological and morphological information is synthesized.

In the phonological representation, Kuznetsova (2018: 235 Fig. 8) associates long vowels with two V-positions, and long (incl. fortis) consonants with two C-positions. Syllable length is defined by morae. However, Kuznetsova does not use morae as syllable constituents, but "as an analytical measure of the syllable's prosodic properties" (ibid.: 231).

Accents in Kuznetsova's model belong to the morphonological representation together with the information about morpheme types. Morpheme types and their accents are predefined:

Roots can have at maximum three prosodic types of allomorphs. First, it is a monosyllabic stem (Rmon) with a heavy accent. Second, it is a multisyllabic "vocalic" stem which carries light accent by default for most words (R, or its abridged variant R-), apart from the class of so-called contracted roots. The latter have the default vocalic stem with a heavy accent (Rs) and also an additional lightly-accented stem (Rw). The default stem for most nouns can be obtained from a genitive singular form, Rw from a partitive singular form. (Kuznetsova 2018: 234)

Derivative suffixes with prosodic properties similar to nouns are marked as ADJ, ADJ-, ADJmon (Kuznetsova 2018: 236). 
Estonian morphemes could be classified into those attracting and nonattracting accent ( $m+$ and $m$ in Fig. 8 [Fig. 9 here]). Accent-attracting morphemes (e.g. all roots, apart for certain unaccented personal pronouns) require an accent either on their first syllable or on the last syllable of a preceding morpheme (like all suprasegmental morphemes and a derivative suffix -nna meaning female actors). (Kuznetsova 2018: 234)

3.2. For example, suur 'big' is classified as an abridged version of a vocalic stem (Kuznetsova 2018: 235 Fig. 8). Vocalic stems carry light accent "by default for most words" (ibid.: 234). Fig. 9 demonstrates the accent calculation for the word form 'suurte, showing how autosegmental light accent gets associated to its domain, the foot (which is not a structural unit).

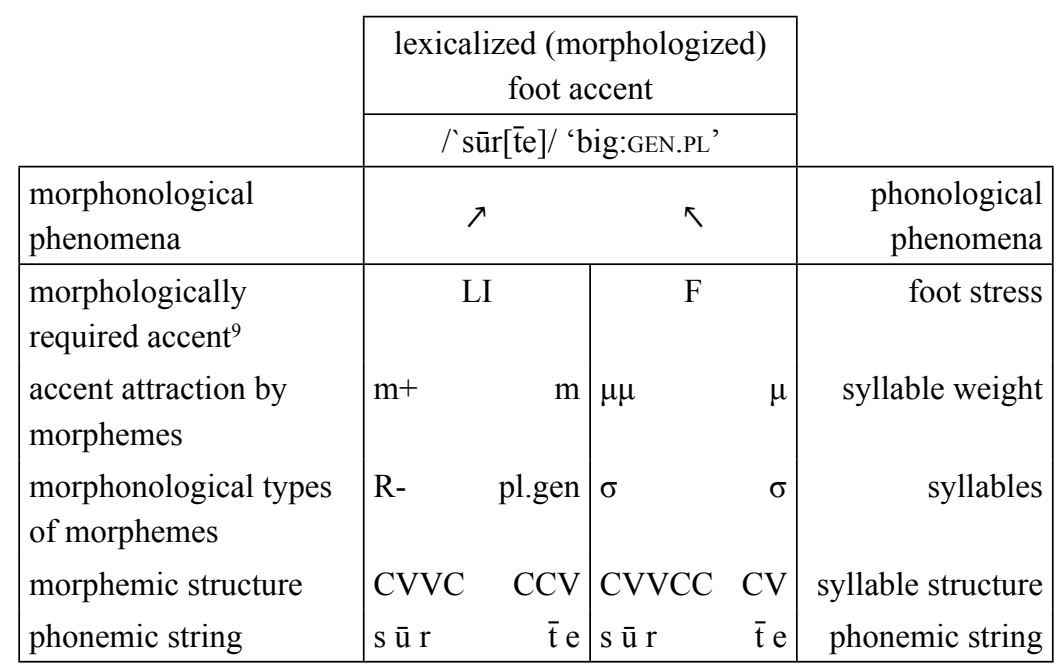

Figure 9. Example calculation of the foot accent in 'suurte (Kuznetsova 2018: 235 Fig. 8).

Prillop (2018b: 447) presents the generation of 'noorte 'young, gen. pl.'. This lexeme, noor, is inflected in exactly the same way as suur. I repeat the analysis here (Fig. 10) with slight modifications. The first modification is that Q2 structure is included in the input (however,

9 The abbreviations $L I$ and $H E$ are not defined in Kuznetsova 2018. Their meaning is clear, however, from the context: $L I-$ light accent, $H E$ - heavy accent. 
if Q2 is treated as default, the presence of the structure in the input is not inevitable).

The first generative step of the structure building algorithm (presented in \$2.5) is to connect the input structures: the input morae will be adjoined to syllables. Next applicable step is to add consonants to syllables. As moraic onsets are universally avoided, the third mora of the input connects to the first syllable. Universally, every syllable needs an onset (if available). Therefore, //t// gets connected to the second syllable as well. To avoid changing segmental length, //r// gets linked directly to the first syllable node, not to a mora. The next step is to repair trimoraic syllables. This is universally done by mora sharing. Note that processes can create structures that were avoided by previously applied processes, for example, not adding //r// to a mora at step (3), but adding it to a mora at step (4). (About processes and ordering effects, see Prillop 2018c.)

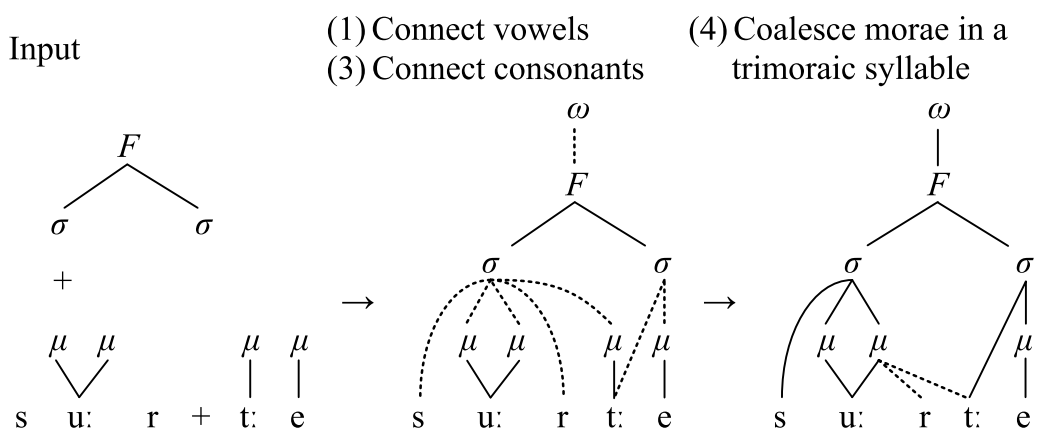

Figure 10. Generation of Q2 suurte in a moraic account (cf. Fig. 5).

Prillop (2018b: 447) presents another structural possibility for noorte/suurte, where $[\mathrm{r}]$ and $[\mathrm{t}]$ are linked directly to the syllable node to avoid mora sharing between three segments. As explained in fn. 6, we do not yet have phonetic data to decide which of the many theoretically possible variants is correct for Estonian (see also §5.5).

3.3. Let us now return to Kuznetsova's algorithm. As her analysis of 'suurte (Fig. 9) suggests, monosyllabic allomorphs of vocalic stems have light accent by default. Vocalic stems can acquire heavy accent if followed by morphemes that require accent "on the last syllable of a preceding morpheme" (Kuznetsova 2018: 234). For example, the 
partitive plural form 'suuri has heavy accent on the first syllable because of the suffix $-i$; see Fig. 11.

\begin{tabular}{|ll|ll|}
\hline \multicolumn{4}{|c|}{ /'sūri/ 'big.PART.PL' } \\
\hline LI &. $\mathrm{HE}^{10}$ & $\mathrm{~F}$ & \\
$\mathrm{~m}+$ & $\mathrm{m} . \mathrm{m}^{+11}$ & $\mu \mu$ & $\mu$ \\
R- & pl.part & $\sigma$ & $\sigma$ \\
CVVC & V & CVVC & V \\
s ū r & i & s u r & i \\
\hline
\end{tabular}

Figure 11. Example calculation of the foot accent in 'suuri (Kuznetsova 2018: 236 Fig. 10a).

Compare this with the generation of Q3 suuri along the lines of Prillop (2018b) in Fig. 12.

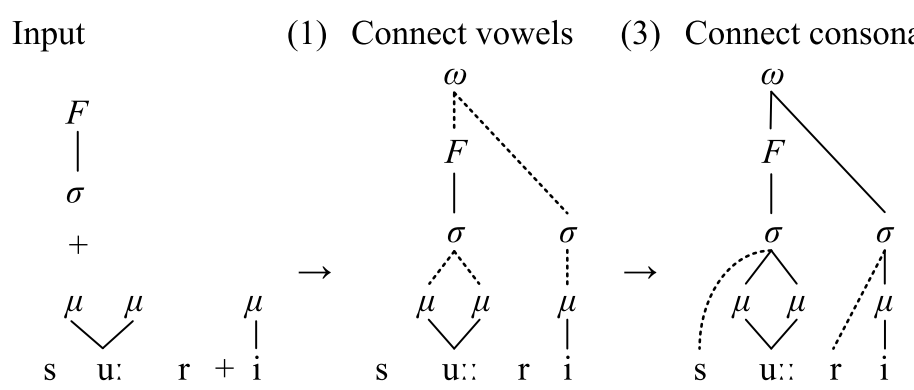

Figure 12. Generation of Q3 suuri in a moraic account.

In Kuznetsova's model, genitive plural -de, I assume (Kuznetsova 2018 does not analyze word forms with -de), is also an accent-attracting suffix. $-d e$ is added to a disyllabic vocalic stem (not to its shortened variant); for example, 'koerade 'dog, gen. pl.', 'soolade 'salt, gen. pl.', 'kiusude 'spite, gen. pl.', etc. (see Table 1). As we already know, vocalic stems carry light accent. Thus, analogously to the partitive

10 The dot before $H E$ is not defined by Kuznetsova (2018). She comments on her Fig. 10a very briefly: "Fig. 10a shows a suprasegmental morpheme of partitive, which changes the accent of the whole foot into heavy." (ibid.: 236).

$11 m . m^{+}-$also not defined by Kuznetsova (2018); compare $m$ for pl.gen (Fig. 9), m.m for comp.gen (Fig.20). 
plural, genitive plural forms must acquire heavy accent because of an accent-attracting inflectional suffix. By Kuznetsova's definition, accentattracting morphemes "require an accent either on their first syllable or on the last syllable of a preceding morpheme" (Kuznetsova 2018: 234; my emphasis). So, does this yield something like *'koe 'rade, *'tai 'mede, *'kol 'mede, *'vaa 'side, *'kiu 'sude?

For comparison, the generation of Q3 soolade in a moraic account is shown in Fig. 13. Secondary stress in trisyllabic Q3 words is optional (see §2.3) - it can be banned by the constraint NoClash 'No stressed syllables are adjacent' (Kager 1999: 165).
(1) Connect vowels
Optional: creating second $F$ blocked by the
Input constraint NOCLASH

(3) Connect consonants

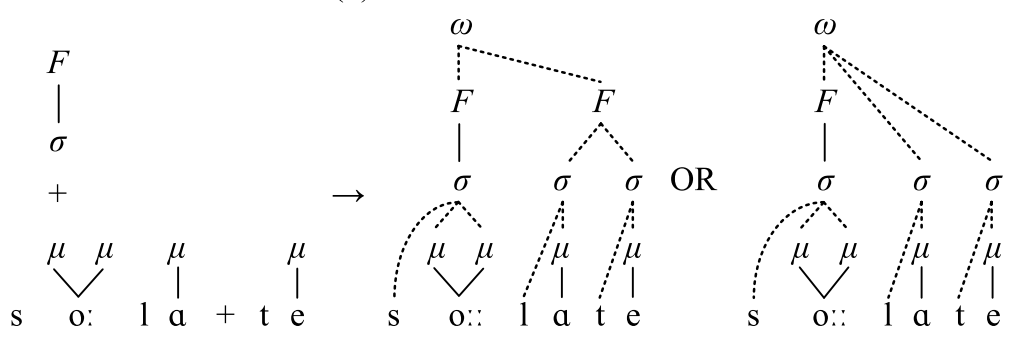

Figure 13. Generation of $\mathrm{Q} 3$ soolade in a moraic account.

One more question arises: Are $-i$ and -de always accent-bearing? If yes, how are we to explain that, for example, puude 'tree, gen. pl.' (nom. sg. puu) may be pronounced in two ways, with a light accent or with a heavy accent, both correct in Standard Estonian (see also §2.7)? If no, do we have to define two different allomorphs, one accent-attracting and the other non-accent-attracting?

3.4. Kuznetsova's statement that accent is required on the last syllable of a preceding morpheme holds in a few cases. Kuznetsova (2018: 234) mentions the derivational suffix -nna as an example. This suffix indeed requires stress (optionally even primary stress) on the syllable that is closed by the geminate $n$ that starts the suffix, namely, on the last syllable of the root. Unlike the suffixes $-d e$ and $-i$, -nna does not affect the accent of the root/stem; for example, Q1 ('ku.nin).('gan.na) 
'queen', Q2 ('lee.du).('lan.na) 'Lithuanian, fem.', Q3 ('võist).le.('jan.na) 'competitor, fem.', and Q3 ('eest).('lan.na) 'Estonian, fem.'. If suffixes like -nna attract accent, not stress, how can we put stress on the right syllable? Does accent require stress?

In a moraic account, the lexical representation of the suffix -nna probably consists of a $\mathrm{Q} 2$ prosodic structure and a bimoraic sequence $/ \mathrm{n}: \mathrm{a} /$. By output generation, the first mora of the suffix will be attached to the first syllable of the Q2 structure because syllable onsets cannot be moraic. This ensures stress on the final syllable of the root. The coda of the root-final syllable is the suffix-initial $/ \mathrm{n} /$, which is attached to the first mora and thereby to the first syllable of the Q2 foot. What happens in the root depends on the structure of the root, not on the -nna suffix; see Fig. 14.

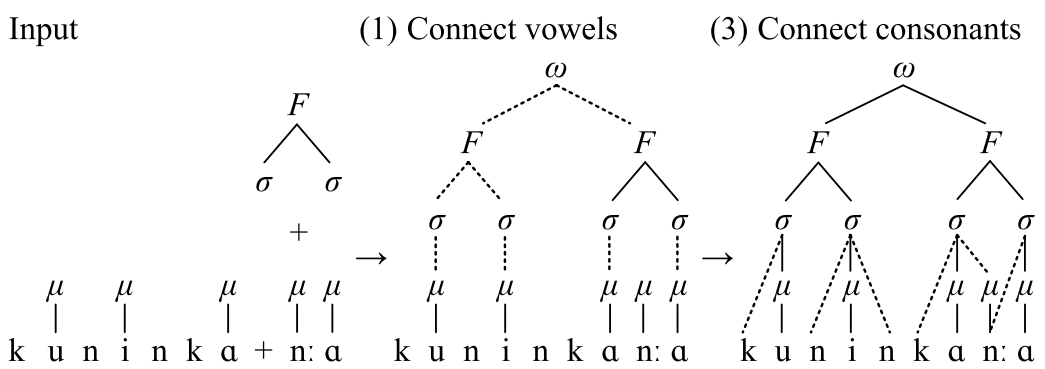

Figure 14. Generating kuninganna.

-lik is another accent/stress-attracting suffix in Estonian. It attracts accent/stress to itself, not to the preceding syllable, and it belongs to the type ADJmon (see Kuznetsova 2018: 237 Fig. 11), which means that it carries heavy accent (ibid.: 234, 236); see Fig. 15. Based on this information, we can correctly calculate 'koeralik (Fig. 16), but not 'kiuslik (Fig. 17), because kius $^{12}$ is a vocalic stem and therefore has light accent (see ibid.: 234), and -lik does not change the accent of the preceding morpheme. How can we get heavy accent on the first syllable of 'kiuslik without simultaneously generating incorrect *'koeralik (assuming that -lik makes the accent of the preceding morpheme heavy) or incorrect gen. sg. *'kiusu, *'koera (assuming that vocalic stems carry heavy accent by default)?

12 nom. sg. `kius, gen. sg. 'kiusu, part. sg `kiusu, gen. pl. `kiusude, part. pl. `kiuse (cf. Table 1). 


\begin{tabular}{|c|c|c|c|c|}
\hline \multicolumn{5}{|c|}{ /'kasu(')lik̄/ 'useful' ('use:ADJ') } \\
\hline LI & $\mathrm{HE}$ & $\mathrm{F}$ & & (F) \\
\hline $\mathrm{m}+$ & $\mathrm{m}+$ & $\mu$ & $\mu$ & $\mu \mu$ \\
\hline $\mathrm{R}$ & ADJmon & $\sigma$ & $\sigma$ & $\sigma$ \\
\hline $\mathrm{CVCV}$ & CVCC & $\mathrm{CV}$ & $\mathrm{CV}$ & CVCC \\
\hline $\mathrm{ka} \mathrm{s} \mathrm{u}$ & $1 \mathrm{i} \overline{\mathrm{k}}$ & $\mathrm{k} \mathrm{a}$ & $\mathrm{su}$ & $1 \mathrm{i} \overline{\mathrm{k}}$ \\
\hline
\end{tabular}

Figure 15. Example calculation of the foot accent in 'kasulik (Kuznetsova 2018: 237 Fig. 11b).

\begin{tabular}{|ll|lll|}
\hline \multicolumn{5}{|c|}{$/$ 'koera(')lik/ 'dog-like' } \\
\hline LI & HE & F & & $(\mathrm{F})$ \\
$\mathrm{m}+$ & $\mathrm{m}+$ & $\mu \mu$ & $\mu$ & $\mu \mu$ \\
$\mathrm{R}$ & ADJmon & $\sigma$ & $\sigma$ & $\sigma$ \\
CVVCV & CVCC & CVV & CV & CVCC \\
k o e r a & $1 \mathrm{i} \overline{\mathrm{k}}$ & k o e & r a & $1 \mathrm{i} \overline{\mathrm{k}}$ \\
\hline
\end{tabular}

Figure 16. Example calculation of the foot accent in 'koeralik.

\begin{tabular}{|ll|ll|}
\hline \multicolumn{4}{|l|}{$* /$ kius(')li $\bar{k} /$ 'pesky' } \\
\hline LI & HE & F & $(\mathrm{F})$ \\
m+ & m+ & $\mu \mu$ & $\mu \mu$ \\
R- & ADJmon & $\sigma$ & $\sigma$ \\
CVVC & CVCC & CVVC & CVCC \\
ki u s & li $\overline{\mathrm{k}}$ & k i u s & li $\overline{\mathrm{k}}$ \\
\hline
\end{tabular}

Figure 17. Example of failure to calculate `kiuslik.

In a moraic account, the generation of such word forms is straightforward, see Fig. 18. 
(1) Connect vowels

Optional: attaching second $F$ to $\omega$ blocked by NOCLASH

Input (3) Connect consonants

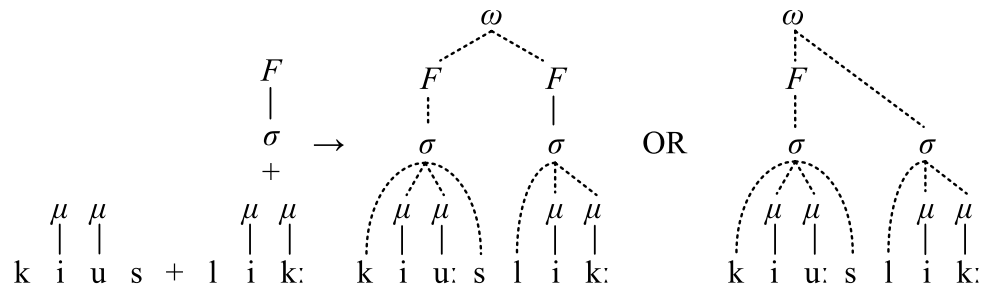

Figure 18. Generating Q3 kiuslik.

According to Kuznetsova's model, there would seem to be a potential for stresses and accents to conflict in any word with a stress/accentattracting derivational suffix (see also §2.3, §7). For example, in Kuznetsova's analysis, pöordeline 'turning' has secondary stress on the second syllable, but light accent on the third syllable; see Fig. 19 (Kuznetsova 2018: 236 Fig. 10b). In the case of 'kasu 'lik 'useful' (Fig. 15), the suffix -lik simply loses its accent if the suffix is pronounced without secondary stress (ibid.: 237, more about it in $\S 4$ ). However, according to Kuznetsova, 'pöörde'line is the calculated output, not 'pöördeline (ibid:: 236 Fig. 10b). It is possible that Kuznetsova's algorithm actually never places secondary stress on the second syllable (i.e., Kuznetsova's Fig. 10b contains an error). In that case, how can disyllabic 'kius ' lik still bear two stresses and two accents?

\begin{tabular}{|ll|llll|}
\hline \multicolumn{5}{|c|}{ /pörde'line/ 'turning' ('turn:ADJ') } \\
\hline $\mathrm{HE}$ & $\mathrm{LI}$ & $\mathrm{F}$ & $\mathrm{F}$ & & \\
$\mathrm{m}+$ & $\mathrm{m}+$ & $\mu \mu$ & $\mu$ & $\mu$ & $\mu$ \\
$\mathrm{Rs}$ & $\mathrm{ADJ}$ & $\sigma$ & $\sigma$ & $\sigma$ & $\sigma$ \\
$\mathrm{CVVCCV}$ & $\mathrm{CVCV}$ & $\mathrm{CVVC}$ & $\mathrm{CV}$ & $\mathrm{CV}$ & $\mathrm{CV}$ \\
$\mathrm{p}[\overline{\mathrm{o}}] \mathrm{rte}$ & li i e & $\mathrm{p}[\overline{\mathrm{o}}] \mathrm{r}$ & $\mathrm{t} \mathrm{e}$ & $1 \mathrm{i}$ & $\mathrm{n} \mathrm{e}$ \\
\hline
\end{tabular}

Figure 19. Calculating foot accents in 'pöörde'line.

3.5. This leads to a fundamental question about Kuznetsova's description of Estonian: Why do we have to differentiate accents and stresses at all? What does it mean that kavalama 'clever, comp. gen. 
sg.' does not have accent on the third syllable, but still has secondary stress on that syllable (Fig. 20)? Does this statement have any phonetic consequences? Will it somehow simplify the morphological description of Estonian?

\begin{tabular}{|ll|llll|}
\hline \multicolumn{5}{|l|}{ /'kavalama/ 'cunning:CPR.GEN' } \\
\hline $\mathrm{LI}$ & $\mathrm{F}$ & \multicolumn{5}{c|}{$\mathrm{F}$} \\
$\mathrm{m}+$ & $\mathrm{m} . \mathrm{m}$ & $\mu$ & $\mu$ & $\mu$ & $\mu$ \\
$\mathrm{R}$ & cmp.gen & $\sigma$ & $\sigma$ & $\sigma$ & $\sigma$ \\
$\mathrm{CVCVCV}$ & $\mathrm{CV}$ & $\mathrm{CV}$ & $\mathrm{CV}$ & $\mathrm{CV}$ & $\mathrm{CV}$ \\
$\mathrm{k} \mathrm{a} \mathrm{v} \mathrm{a} \mathrm{l} \mathrm{a}$ & $\mathrm{m} \mathrm{a}$ & $\mathrm{k} \mathrm{a}$ & $\mathrm{v} \mathrm{a}$ & $1 \mathrm{a}$ & $\mathrm{m} \mathrm{a}$ \\
\hline
\end{tabular}

Figure 20. Calculating foot accents in 'kavalama (Kuznetsova 2018: 235 Fig 9b).

As the above examples show, Kuznetsova tries to describe Estonian morphonology. She does not deal with phonetics-phonology interactions. However, in her criticism of previous accounts, she concentrates on phonetics: reduction of vowels, duration of morae, etc. Yet, her real contenders should be the various models of Estonian morphology.

\section{Derivatives like kasulik are not in the midst of changing their declension type}

To support her structural functional treatment of the Estonian quantity system, Kuznetsova (2018: 236) claims (my emphasis):

A trisyllabic word can be composed of two feet, but this is a marked stress model and there is a tendency to lose the stress of a final monosyllabic foot. This, however, does not seem to happen if such a foot contains a root morpheme (1[1]a) [shows calculating foot accents in the compound tul[e]tikk 'match (fire+stick)'; not reproduced here], while it is more common in adjective derivative suffixes (1[1]b) [Fig. 15 here, see §3.4]. As a result, derivatives like kasulik 'useful' in Fig. 11b face a prosodic conflict between phonology and morphonology. On the one hand, the foot structure can manifest a lack of the second foot stress. On the other hand, the system of prosodic morphonological alternations imposes heavy accent on the last syllable. Eventually, to resolve this conflict such words start changing their declension type, as 
described by Hint (1978) and Viitso (1982). A functional-structural description of accents, which takes into account both phonological and morphonological information, can predict such changes in the system, as it clearly traces this prosodic conflict.

Kuznetsova is correct in that Estonian word-final syllables may lose their secondary stress. However, Estonian linguists, including Hint (1978) and Viitso (1982), have never observed any change of the declension type of the first quantity (Q1) and second quantity (Q2) derivatives like kasulik. Hint (1978: 40) actually writes (my emphasis):

In the standard literary language derivational suffixes ending in $-\boldsymbol{i k}$ are subjected to grade alternation (prosodic alternation in different morphological forms [e.g. gen. sg. kasuliku (Q2 -iku), part. sg. kasulikku (Q3 -ikku), gen. pl. kasulikkude (Q3) or kasulike (Q2)]), if the suffix is added to a monosyllabic root in Q3 or to a polysyllabic (most commonly disyllabic) stem in Q1 or Q2: [---]

Within this system a monosyllabic stem in Q3 is equal to a disyllabic stem in Q1 or Q2: in both cases there are two morae before the alternating suffix. The inevitable premis for the prosodic quantity alternation in -ik-suffixes is that at least two morae must precede.

In the colloquial language this pattern has changed: the words with monosyllabic Q3 root before $i k$-suffixes have shifted to a gradationless pattern in all morphological word-forms:

part. sg.: [Q2 -iku-] o'htlikut ['dangerous', nom. sg. disyllabic o `htlik, grave accent before syllable coda indicates Q3], maa'stikut ['landscape'], luu`stikut ['skeleton'], kuń'stnikut ['artist'];

gen. pl.: [Q2 -iku-] o'htlikute, maa`stikute, luu`stikute, kun'stnikute; part. pl.: [Q2 -iku-] o`htlikuid, maa`stikuid, luu`stikuid, kuństnikuid (where -te in the gen. pl. forms is a plural marker following the gradationless pattern, $-i$ - is a plural marker in the part. pl. forms and $-t,-d$ are partitive endings in the gradationless type).

In gradationless forms even the quantity degree of the first syllable may be indistinct (not clearly Q3) and the suffix loses its secondary stress.

In colloquial Estonian, only words with one syllable before the suffix -Cik (i.e. Q3 words) are in the midst of changing their declension type. Words with two syllables before -Cik (e.g., kasulik) retain their declension type: part. sg. kasulikku (never kasulikut), gen. pl. kasulike or kasulikkude (not kasulikute), part. pl. kasulikke (not kasulikuid). 


\section{Erroneous citations about Estonian pitch, Estonian diphthongs, and Soikkola Ingrian}

5.1. Further erroneous citations in Kuznetsova's paper are even easier to find. Külli Prillop $(2015,2018$ a) does not claim that pitch in Estonian always falls after the second mora, that Estonian diphthongs are monomoraic, that Soikkola Ingrian tends to preserve original durational contrasts, etc. Yet Kuznetsova (2018: 224-225) writes:

Prillop (2015: 176) also claims that pitch in Estonian always falls after the second mora. This would imply that in Q1 (cf. ude in 2a [table 2 is not reproduced here]) the pitch would fall inside the second syllable vowel. Ample experimental research since the 1930s has shown that pitch in Q1 falls more or less at the same place as in Q2, i.e. at the border between the first and the second syllable (see Lippus et al. 2009, 2013 for the latest results). Moreover, a simulated shift of the peak from the first vowel to the second in Q1 changed the native perception of primary stress patterns: 'kanata ['gana(')t'a] 'hen:ABE' was perceived as $k a$ 'natta [ $\stackrel{\circ a}{a}$ 'nat: 'a] 'also fishpot:PART' (Eek and Meister 2003: 910). Prillop (2018a: 356) already placed the pitch fall after the first mora, the same way as Plüschke (2013: 33).

Prillop (2015: 175-176) actually writes as follows:

Kolmemooraliste silpide võimalikkuse ja vajalikkuse üle on palju vaieldud. Näiteks Bruce Hayes (1989: 291-197, 1995: 163) ei kahtle nende olemasolus. Kolmemooraliste silpide abil oleks eesti väldete kirjeldus äärmiselt lihtne, [---].

[---] Kui oletada, et I välte rõhutu poolpikk vokaal on kahemooraline (nt Pajusalu 2002) ja kustutada III välte rõhutu vokaaliga seotud moora (sest see vokaal on redutseerunud), oleks kõik jalad täpselt kolmemooralised. Lihtne oleks seletada ka toonierinevusi: kui oletada, et põhitooni langus peab olema teise ja kolmanda moora piiril, siis I välte puhul jääks see rõhutusse silpi, III välte puhul aga suhteliselt sõna algusesse, rõhulisse silpi. Kuna kõik jalad peaksid olema vähemalt kolmemooralised, leiaks loogilise seletuse ka tõsiasi, et ainult III välte silbile saab vahetult järgneda rõhuline silp.

Paraku, lisaks kolmemooraliste vokaalide teoreetilisele küsitavusele, ei sobi selline kirjeldus päris hästi mõõtmistulemustega. Kolmemooraline vokaal peaks olema kolm korda pikem kui ühemooraline vokaal, kuid tegelikkuses on III välte vokaal I välte vokaalist ainult umbes 2,5 korda pikem. I välte rõhulise ja rõhuta silbi suhe mudeli järgi on $1 / 2$, kuid 
peaks olema $2 / 3$ või isegi $4 / 5$, st teine silp on mudelis liiga pikk. Ka II välte silpide erinevused on mudelis liiga suured.

[The possibility of and need for trimoraic syllables has been much debated. For example, Bruce Hayes (1989: 291-197, 1995: 163) does not doubt their existence. A description of the Estonian quantity system based on trimoraic syllables would be very simple, [---].

[---] If we assume that an unstressed half-long vowel in a Q1 word is bimoraic (e.g. Pajusalu 2002) and we delete the mora associated with an unstressed vowel in a Q3 word (because the vowel is reduced), then all feet would be exactly trimoraic. It would also be easy to explain tonal differences: if we assume that a pitch fall must lie between the second and third morae, then for Q1 the pitch fall would be in the unstressed syllable, while in Q3 it would fall toward the beginning of the word, in the stressed syllable. As all feet should be minimally trimoraic, this would also lead to a logical explanation for the fact that stressed syllables can directly follow only Q3 syllables.

Unfortunately, in addition to the questionable theoretical status of trimoraic vowels, this type of description is not exactly compatible with measurement findings. Trimoraic vowels should be three times as long as monomoraic vowels, but in reality Q3 vowels are only about 2.5 times as long as Q1 vowels. The ratio of stressed to unstressed syllables in Q1 words, according to the model, is 1:2, but it should be 2:3 or even $4: 5$, meaning that the second syllable in the model is too long. The differences between syllables in Q2 words in the model are also too great.]

Prillop's paper (2015) deals with the problems that arise when modelling the Estonian quantity system by means of moraic theory. Prillop's model of the Estonian quantity system is represented on page 184 (see also Prillop 2013), on the previous pages Prillop presents alternative options and explains why they are not suitable for Estonian. So, Prillop (2015: 176) does not claim that pitch in Estonian always falls after the second mora; on p. 176 she just questions trimoraic syllables as a possible means of describing Estonian quantities (see the citation above).

5.2. Kuznetsova's conclusion that "Prillop (2018a: 356) already placed the pitch fall after the first mora" (Kuznetsova 2018: 225) is also a fallacy. Prillop (2018a: 356) writes (my emphasis): 
Võimalik, et põhitooni muutumist saab siduda ka otseselt mooradega (vt joonist 13): jala esimene moora on seotud kõrge tooniga (H, high), mis laieneb ka järgnevatele mooradele samas jalas, kuid jala lõpus peab toon olema langenud madalaks ( $\mathrm{L}$, low), mistõttu viimane moora on langeva tooniga $(\mathrm{HL})$.

[It may be possible to relate the change in pitch directly to morae (see Fig. 13 [not reproduced here]): the first mora in a foot is associated with high pitch $(\mathrm{H})$, which spreads to the following morae in the same foot, but the pitch must have fallen to low (L) by the end of the foot. Hence, the final mora [i.e. the second or third one in the feet shown in Fig. 13] has falling pitch (HL).]

5.3. Even more far-fetched is Kuznetsova's (2018: 228) statement that Prillop treats (some) Estonian diphthongs as monomoraic:

While long vowels are always treated as bimoraic, first syllable diphthongs are treated as either monomoraic (sharing a mora) or bimoraic, depending on the quantity degree (Prillop 2015: 177). However, initial syllable diphthongs and long vowels manifest the same prosodic behavior, so it remains unclear why the two should be represented differently.

The possibility of treating Q2 diphthongs as monomoraic has been suggested by Ehala (2003). Prillop (2015: 177) comments on that possibility without approving it:

Kui kohandada samad skeemid diftongidele, oleks diftongi teine osis ilma moorata ja seega poolvokaal või tugevalt redutseerunud. See pole aga kooskõlas foneetiliste faktidega. Paremini sobiks variant, kus ühemooralise diftongi mõlemad osised jagavad sama moorat, vt joonis 8, kuigi ka sel juhul tekkib vastuolu foneetikaga, sest III vältes oleks diftongi mõlemad osised (mitte ainult teine) pikemad kui II vältes.

[If we adapt the same schemes [these "schemes" refer to the directly preceding discussion in Prillop, 2015, pp. 176-177, which are not reproduced here] to diphthongs, the second part of the diphthong would be nonmoraic, hence a semi-vowel or strongly reduced. This, however, is not in accord with the phonetic facts. A better solution would be one in which both components of a monomoraic diphthong share the same mora, see Fig. 8 [not reproduced here], but this too results in incompatibility with phonetics, because both components (not just the second) of a diphthong in Q3 words would be longer than those of diphthongs in Q2 words.] 
5.4. In the quotation 'Prillop (2015: 190) claimed that Soikkola Ingrian "tends to preserve original durational contrasts of words, syllables and segments"' (Kuznetsova 2018: 228), the original Estonian verb pü̈ü 'tries to' is translated as tends to, which reverses the meaning of Prillop's original thought. Prillop's idea is, that a contemporary full vowel (originally long vowel) in Soikkola Ingrian is associated with a prominent mora, which prevents reduction, and an originally short vowel is associated with a non-prominent mora, which cannot prevent reduction (Prillop 2015: 189-191). Thus, contrary to what Kuznetsova (2018: 228-229) claims, Prillop agrees that an original short vs. long vowel contrast in Soikkola Ingrian turns into a reduced vs. short vowel contrast.

5.5. My last example is the following:

In the earlier version [= Prillop 2013], it [= mora] could also split between three segments (Fig. 7c [like Fig. 10 here]). In the later version [= Prillop 2018a,b], this issue is resolved by projecting both parts of the geminate directly to a syllabic level (Fig. 7e) [Fig. 21 here]. However, such a representation violates one of the basic principles outlined above: a long (fortis) consonant should have one mora (in Fig. 7e [Fig. 21 here], it has none). Notably in a monosyllabic form 'suurt 'big:PART' the final fortis consonant has a mora (Prillop 2018a: 360). Unfortunately, clear criteria to distinguish between the cases of fortis consonants with and without a mora were missing. (Kuznetsova 2018: 227-228; my emphasis)

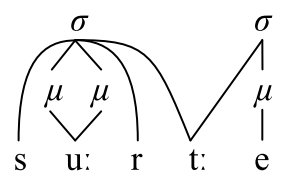

Figure 21. Nonmoraic geminate [t:] in a Q2 word (cf. Fig. 5, Fig. $10)$.

Only one context where fortis can lose its underlying mora during the output generation process is mentioned by Prillop. The criterion is given within the analysis of CVVCG syllables in Q2 words (like suurte in Fig. 21): "Foot-medially (e.g., in word forms kaarte, keelte), the lexically moraic stop surfaces as a short, nonmoraic geminate." (Prillop 2018a: 360). Geminates do not have to be moraic in surface forms. An ambisyllabic consonant is perceived as long, even if it is nonmoraic. 
The structure represented in Fig. 21 will appear if we add one more phonological constraint to the structure building algorithm provided in $\S 2.5-\mathrm{a}$ ban on mora sharing foot-medially. It is not inevitably necessary in contemporary Estonian. However, Prillop (2018b) adds a historical perspective to explain how these structures may have emerged and spread in Estonian. In Old Estonian, a moraic stop lost its mora footmedially if preceded by two morae. Therefore, Estonian has a lenisgeminate alternation in words like niidu [ni:tu] 'field, gen. sg.', niitu [ni:t:tu] 'field, part. sg.' (nom. sg. niit [ni:t:]). Foot-medial geminate $t$ in such a position evolved later from nonmoraic $/ \mathrm{t}+\mathrm{t} /$ sequences; for example, *(uut.+ten) > (uut.te) 'new, gen. pl.' (Prillop 2018b: 445-446).

\section{Vowel reduction in Estonian is not directly linked to vowel duration}

6.1. Kuznetsova (2018: 225) writes about Ilse Lehiste's findings: "Phonetic results by Lehiste (1997b: 150-151) showed that in trisyllabic Q3 words V2 is also reduced, but not V3". Lehiste (1997) does not even mention reduction. True, she provides data about vowel durations, but contrary to Kuznetsova's assumption, reduction in Estonian is not directly linked to duration. Arvo Eek, who has thoroughly studied the quantity and quality of Estonian vowels, writes (Eek 2008: 103-104):

Q3 sõna rõhuta silbi vokaali kvaliteedi suurimat reduktsiooni ei saa mitte alati põhjendada ainult vokaali lühidusega, sest Q3 sõna lühikeste ja Q2 sõna nn poolpikkade rõhuta vokaalide kestused on mõnikord minimaalselt erinevad (vt ka tabelit 2.8). Pigem peegeldab Q3 sõnade rõhuta silbi vokaalide kvaliteedi Q1 ja Q2 sõnadest tugevam redutseeritus P. Ariste kirjeldatud rõhu erinevast tsentraliseerivast mõjust tulenevaid väldete iseloomulikke hääldusmalle.

[We cannot always use the vowel's short duration to justify the fact that the greatest reduction of vowel quality occurs in unstressed syllables of Q3 words [compared to Q1 and Q2 words], because the durations of short vowels in Q3 words and so-called half-long unstressed vowels in Q2 words sometimes differ only minimally (see also table 2.8 [not reproduced here]). The stronger reduction of vowel quality in unstressed syllables of Q3 words than Q1 and Q2 words reflects, rather, characteristic pronunciation patterns influenced by the different centralising effects of stress, as described by P. Ariste.] 
6.2. Kuznetsova does not even mention the findings of Eek. She just assumes that shortness and reduction are the very same thing, and argues (Kuznetsova 2018: 225):

The phonetic reduction of $\mathrm{V}_{2}$ in $\mathrm{Q} 3$ disyllables (cf. 'uude 'new.ILL' and other types in 3a-e, Table 2 [not reproduced here]) was used as an argument supporting Prince's idea that a Q3 syllable exhausts the foot (Prillop 2015: 182). This $\mathrm{V}_{2}$ is claimed to be reduced exactly because it does not belong to the foot. One could wonder if the same claim should then hold for an unstressed $V_{3}$ in trisyllables. Prillop (2018a: 351) sees the foot as maximally disyllabic. Phonetic results by Lehiste (1997b: 150-151) showed that in trisyllabic Q3 words $\mathrm{V}_{2}$ is also reduced, but not $V_{3}$. The length of $V_{3}$ is generally comparable to the length of a full short $V_{1}$, irrespective of the quantity degree of the foot. Exactly for this reason, Eek and Meister (1997: 95) phonologically treat $V_{3}$ as not belonging to their "minimal foot", while $\mathrm{V}_{2}$ is included. If both $\mathrm{V}_{2}$ and $\mathrm{V}_{3}$ do not belong to the foot, as Prillop's conception implies, vowel reduction cannot be considered as a sign of syllable's extrametricality.

It is true that the length of V3 is comparable to the length of V1. However, the length of V3 is also comparable to the length of V2 in Q3 words; see Table 4 (taken from the same source that Kuznetsova cites, Lehiste (1997: 150)). Word-final unfooted vowels have slightly longer durations than word-medial unfooted vowels. This has a simple explanation: word-final lengthening. Such lengthening is also evident in other data sets, such as Pajusalu et al. (2005: 105), which is obviously known to Kuznetsova (she cites it). For example, average vowel durations in pentasyllabic (CV1.CV2).(CV3.CV4).CV5 words in the speech of three informants from western Saaremaa are:

V1 (primary stress) $-95 \mathrm{~ms}$,

V2 (unstressed, first foot) - $91 \mathrm{~ms}$,

V3 (secondary stress) $-57 \mathrm{~ms}$,

V4 (unstressed, second foot) $-72 \mathrm{~ms}$,

V5 (unstressed, unfooted) — $82 \mathrm{~ms}$ (see Pajusalu et al 2005: 103).

The final vowel is even longer than the secondary stressed vowel. Thus, the duration of $57 \mathrm{~ms}$ cannot indicate reduction of the vowel. Most probably, the shortness of the vowel helps to identify feet: In an ideal Q1 foot, the second vowel (if the syllable is open) is longer than 
the first vowel. The durational ratio $\mathrm{V} 4 / \mathrm{V} 3=1.26$ may signal secondary stress (see also §2.4). ${ }^{13}$ The durational patterns in even longer words are more complicated.

Table 4. Durational patterns in ten word types. Average durations in milliseconds. (Lehiste 1997: 150). My additions to the table are: (1) the 'Structure' column, (2) the gray backgrounds, indicating the durations of unfooted vowels.

\begin{tabular}{|c|c|c|c|c|c|c|c|c|c|}
\hline \multicolumn{2}{|c|}{ Word type } & \multirow{2}{*}{$\begin{array}{l}\text { Structure } \\
(m i . d a) \cdot g i\end{array}$} & \multirow{2}{*}{$\begin{array}{l}\mathrm{N} \\
60\end{array}$} & \multirow{2}{*}{$\begin{array}{c}\mathrm{V} 1^{14} \\
82\end{array}$} & \multirow{2}{*}{$\begin{array}{c}\mathrm{C} 1 \\
45\end{array}$} & \multirow{2}{*}{$\begin{array}{c}\mathrm{V} 2 \\
138\end{array}$} & \multirow{2}{*}{$\begin{array}{r}\mathrm{C} 2 \\
58\end{array}$} & \multirow{2}{*}{$\begin{array}{l}\mathrm{V} 3 \\
82\end{array}$} & \multirow{2}{*}{$\begin{array}{l}\text { MF } \\
405\end{array}$} \\
\hline 1. Q1 & midagi & & & & & & & & \\
\hline 2. $\mathrm{Q} 1$ & kadaka & $(k a \cdot d a k) \cdot k a$ & 30 & 86 & 48 & 111 & 190 & 78 & 513 \\
\hline 3. Q2 & nendega & (nen.de).ga & 15 & 146 & 45 & 99 & 52 & 80 & 422 \\
\hline 4. Q2 & vaadata & (vaa.dat).ta & 65 & 155 & 48 & 77 & 156 & 75 & 511 \\
\hline 5. Q3 & moonide & $\begin{array}{l}(m o o) \cdot n i \cdot d e \sim \\
(m o o) .(n i \cdot d e)\end{array}$ & 35 & 231 & 49 & 64 & 51 & 75 & 469 \\
\hline 6. Q3 & valgete & $\begin{array}{l}\text { (val).get.te } ~ \\
(\text { val }) .(\text { get.te })\end{array}$ & 15 & 256 & 61 & 62 & 139 & 70 & 588 \\
\hline 7. Q2 & tapetud & (tap.pet).tud & 15 & 89 & 100 & 60 & 147 & 70 & 465 \\
\hline 8. Q3 & keegi & (kee).gi & 84 & 255 & 62 & 83 & & & 401 \\
\hline 9. Q3 & kaupa & (kaup).pa & 54 & 185 & 205 & 79 & & & 468 \\
\hline 10. Q3 & kokku & $(k o k) \cdot k u$ & 74 & 81 & 289 & 86 & & & 456 \\
\hline
\end{tabular}

\section{Basic phonological facts about Estonian stress system are known well enough}

7.1. Kuznetsova (2018: 210) writes (my emphasis):

There is still not a final consensus on stress placement rules among Estonian phonologists and phoneticians (cf. latest remarks in Hint 2001: 253-257, Pajusalu et al. 2005: 100, Asu and Lippus 2018). Estonian stress requires further phonetic and phonological investigation, so the very facts which form the basis for most moraic accounts of

13 One cannot argue that perhaps the fourth syllable is stressed, not the third one. Pajusalu et al. also measured the structure (CV1.CV2).CV3.(CV4.CV5): $107 \mathrm{~ms}, 96 \mathrm{~ms}, 80 \mathrm{~ms}$, $92 \mathrm{~ms}, 125 \mathrm{~ms}(\mathrm{~V} 5 / \mathrm{V} 4=1.36)$. Note that in their analysis, feet may be trisyllabic; they do not use the term unfooted.

14 The durations $146 \mathrm{~ms}$ for V1 in nendega and $256 \mathrm{~ms}$ for V1 in valgete are actually the durations of the first syllable nuclei (vowel + sonorant). 
Estonian are still to be verified. This remark made, Estonian stress will be left aside here.

I do agree that Estonian stress needs further investigation. However, I am of the opinion that the basic facts which form the core of phonological (incl. moraic) accounts of Estonian are verified well enough. Kuznetsova itself relies on the same basic knowledge (see §3).

The most recent comprehensive study of Estonian phonetics (Asu et al. 2016: 127) concludes:

Eesti keele rõhu reeglitest on küllaltki selge fonoloogiline ettekujutus, kuid eksperimentaalfoneetiliselt on rõhku väga vähe uuritud.

[We have a fairly clear phonological understanding of the rules of Estonian stress patterns, but very few studies have investigated stress using experimental phonetic methods.]

True, many decades ago, there were debates about the placement of secondary stress in Q3 words. The most controversial issue was whether a Q3 syllable can, cannot or must be followed by a secondary stressed syllable in longer words. Hint (2001: 253-257) made clear that a Q3 syllable can be (but does not need to be, see also §2.3) followed by a secondary stressed syllable. This conclusion is accepted in contemporary phonological descriptions of Estonian: Viitso 2003: 17, Eek and Meister 2004: 352, Ehala 2003: 70-71, Prillop 2013, 2015: 188, 2018a,b, to name just works cited by Kuznetsova.

7.2. The other papers that Kuznetsova mentions (Pajusalu et al. 2005: 100, Asu and Lippus 2018) deal with phonetics, not with phonological stress placement rules. Asu and Lippus (2018) search for the acoustic correlates of secondary stress in words consisting of five and six CV syllables (Q1 words). "[---] the placement of secondary stresses is determined by morphological constraints but typically coincides with odd-numbered syllables" (Asu and Lippus 2018: 602). Pajusalu et al. (2005: 98-100) give the same basic rule in more detail along with a brief historical overview. The aim of Pajusalu et al. (2005) is to measure vowel durations in tetra-, penta-, and hexasyllabic words and test the hypothesis that every unstressed open syllable vowel in every Q1 foot is half-long. To conduct their measurements, they were able to differen- 
tiate binary and ternary stress patterns (i.e. (CV.CV).(CV.CV).CV and (CV.CV).CV.(CV.CV); see §6.2).

A wide range of durational, pitch-related and spectral measures that Asu and Lippus (2018) test fail to differentiate secondary stressed syllables and unstressed syllables. However, even if younger Estonians do not have clear secondary stress in long words consisting of CV syllables, this does not affect the phonological description of the Estonian quantity system, because "[t]he only exception is the unstressed syllable following the primary stressed syllable that behaves differently from other unstressed syllables. This finding also underlines the important role of the primary stressed foot in the prosodic system of the Estonian language, as the primary stressed foot seems to be the domain for durational as well as intensity differences, among others." (Asu and Lippus 2018: 605)

\section{Other inaccuracies}

Kuznetsova's paper also contains a number of minor errors. For example, contrary to what Kuznetsova claims, crossing association lines are not a shortcoming of mora splitting (p. 219); second syllable vowels in closed syllables do not lengthen (see Asu and Teras 2009), thus ['gana(')t'a] is an incorrect transcription (p. 225); Kager (1992) treats Estonian as having Generalized Trochee, not "syllabic rather than moraic trochee" (p. 226);.HE and $m . m+$ (p. 236) are undefined; Table 1 (p. 217) does not contain the foot type 'VCCC, which is quite common in Estonian (e.g., pilk 'look, glance', pulss 'pulse', vonklema 'wriggle').

\section{A closing remark}

Considering all its inaccuracies and misinterpretations, in my opinion Kuznetsova's paper does not solve any problem in Estonian phonology or morphonology. Estonian has much to contribute to the development of phonological theory. However, it is far from being a language with an extraordinarily complex prosodic structure that cannot be adequately analyzed within moraic theory (as Kuznetsova aspires to prove; see Kuznetsova 2018: 234). 
For comparison with Estonian, consider, for example, Syrian Arabic geminates as interpreted by Kiparsky (2003) in Fig. 22a, Franconian accents as described by Köhnlein and Cameron (2019) in Fig. 22b, or Shilluk vowel overlength as interpreted after phonetic measurements by Remijsen et al. (2019) in Fig. 22c. Investigating complex structures in many different languages, comparing them on uniform basis, and searching for their differences and similarities - that is what may lead to a better understanding of human language.

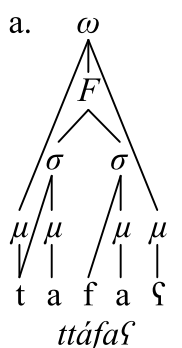

b.

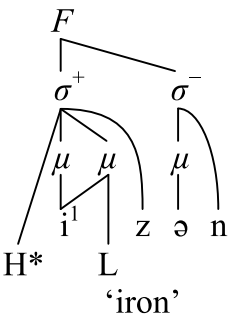

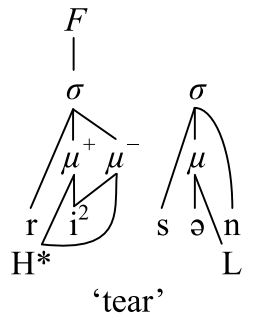

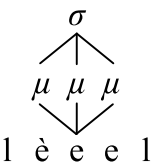

'he agreed'

Figure 22. a. Syrian Arabic initial geminates (Kiparsky 2003: 160), b. Franconian tones: disyllabic foot $v s$. monosyllabic foot (Köhnlein and Cameron 2019), c. Shilluk overlength (Remijsen et al. 2019).

\section{Acknowledgements}

This research has been supported by the European Regional Development Fund (Centre of Excellence in Estonian Studies).

\section{Address:}

Külli Prillop

Institute of Estonian and General Linguistics

University of Tartu

Jakobi 2-445

51014 Tartu, Estonia

E-mail: kulli.prillop@ut.ee 


\section{References}

Asu, Eva Liina and Pärtel Lippus (2018) "Acoustic correlates of secondary stress in Estonian”. In Katarzyna Klessa, Jolanta Bachan, Agnieszka Wagner, Maciej Karpiński, and Daniel Śledziński, eds. 9th international conference on speech prosody 2018, 13-16 June 2018, Poznań, Poland, 602-606. Poznań: Adam Mickiewicz University. https://doi.org/10.21437/SpeechProsody.2018-122

Asu, Eva Liina and Pire Teras (2009) "Illustrations of the IPA: Estonian". Journal of the International Phonetic Association 39, 3, 367-372. https://doi.org/10.1017/S002510030999017X

Asu, Eva Liina, Pärtel Lippus, Karl Pajusalu, and Pire Teras (2016) Eesti keele hääldus. (Eesti keele varamu, 2.) Tartu: Tartu Ülikooli Kirjastus.

Eek, Arvo (2008) Eesti keele foneetika I. Tallinn: TTÜ kirjastus.

Eek, Arvo and Einar Meister (2003) "Foneetilisi katseid ja arutlusi kvantiteedi alalt (I). Häälikukestusi muutvad kontekstid ja välde”. Keel ja Kirjandus 11, 815-837; 12, 904-918.

Eek, Arvo and Einar Meister (2004) "Foneetilisi katseid ja arutlusi kvantiteedi alalt (II). Takt, silp ja välde". Keel ja Kirjandus 4, 251-271; 5, 337-357.

Ehala, Martin (2003) "Estonian quantity: implications for Moraic Theory". In Diane Nelson and Satu Manninen, eds. Generative approaches to Finnic and Saami linguistics, 51-80. Stanford: CSLI Publications.

Hint, Mati (1978) "Changes in the prosodical system of contemporary Estonian". In Arvo Eek, ed. Estonian Papers in Phonetics, 39-43. Tallinn: Institute of Language and Literature.

Hint, Mati (1986) "Viron prosodisen systeemin perusluonteesta. Historiallinen näkökulma”. Virittäjä 4, 428-440.

Hint, Mati (1997) "The Estonian quantity degrees in prosody and morphonology". In Ilse Lehiste and Jaan Ross, eds. Estonian prosody, 125-135. Tallinn: Institute of Estonian Language.

Hint, Mati (2001) "Prosoodiaväitlustes läbimurdeta". Keel ja Kirjandus 3, 164-172; 4, $252-258 ; 5,324-339$.

Kager, René (1992) "Shapes of the generalized trochee". In Jonathan Mead, ed. The proceedings of the eleventh West Coast conference on formal linguistics, 298-312. Chicago: University of Chicago Press.

Kager, René (1996) "On affix allomorphy and syllable counting”. In U. Kleinhenz, ed. Interfaces in phonology, 155-171. Berlin: Akademie Verlag.

Kager, René (1999) Optimality theory. Cambridge: Cambridge University Press.

Kiparsky, Paul (2003) "Syllables and moras in Arabic". In C. Féry, R. van de Vijver, eds. The syllable in optimality theory, 147-182, Cambridge: Cambridge University Press. https://doi.org/10.1017/CBO9780511497926.007

Köhnlein, Björn and Ian S. Cameron (2019) "The influence of consonantal strength on foot assignment in accentual systems". Talk presented at the 27th Manchester Phonology Meeting, Thursday 23rd - Saturday 25th May 2019, UMIC, Manchester. 
Kuznetsova, Natalja (2018) "Estonian word prosody on the Procrustean bed of morae". Journal of Estonian and Finno-Ugric Linguistics 9, 1, 209-244. https://doi.org/10.12697/jeful.2018.9.1.09

Lehiste, Ilse (1997) “The structure of trisyllabic words". In Ilse Lehiste, Jaan Ross, eds. Estonian prosody, 149-164. Tallinn: Institute of Estonian Language.

Pajusalu, Karl, Toomas Help, Pärtel Lippus, Ellen Niit, Pire Teras, and Tiit-Rein Viitso (2005) "On the temporal structure of Estonian secondary-stressed feet". Linguistica Uralica 41, 2, 98-106.

Peebo, Jaak (1997) Eesti keele muutkonnad. Tartu: Tartu Ülikooli eesti keele õppetool.

Prillop, Külli (2013) "Feet, syllables, moras and the Estonian quantity system". Linguistica Uralica 49, 1, 1-29. https://doi.org/10.3176/lu.2013.1.01

Prillop, Külli (2015) "Hääliku-, silbi- ning jalavälde: ühe nähtuse mitu tahku". Journal of Estonian and Finno-Ugric Linguistics 6, 3, 169-195.

https://doi.org/10.12697/jeful.2015.6.3.07

Prillop, Külli (2018a) “Mida teeb moora eesti keeles?”. Keel ja Kirjandus 5, 345-364.

Prillop, Külli (2018b) "Varjatud muutused eesti keele prosoodilises struktuuris". Keel ja Kirjandus, 6, 433-452.

Prillop, Külli (2018c) "Interacting processes in phonological theory”. Phonology 35, 3, 441-479. https://doi.org/10.1017/S095267571800012X

Prince, Alan (1980) “A metrical theory for Estonian quantity”. Linguistic Inquiry 11, 3, 511-562.

Remijsen, Bert, Otto Gwado Ayoker, and Signe Jørgensen (2019) “Ternary vowel length in Shilluk". Phonology 36, 1, 91-125. https://doi.org/10.1017/S0952675719000058

Viitso, Tiit-Rein (1982) “Morosčitajuščij li jazyk èstonskij?”. Sovetskoe finno-ugrovedenie 8, 1, 8-20.

Viitso, Tiit-Rein (2003) "Structure of the Estonian language: phonology, morphology and word formation". In Mati Erelt, ed. Estonian language, 9-92. (Linguistica Uralica Supplementary Series, 1.) Tallinn: Estonian Academy Publishers.

\section{Kokkuvõte. Külli Prillop: Moorad eesti keeles. Vastus Natalja Kuznetsova artiklile "Eesti sõnaprosoodia moorade Prokrustese sängis". Vastus Natalja Kuznetsovale toob välja mitu küsitavat tõlgendust ja tulemust, kümme tõsist viga ja viis väiksemat ebatäpsust tema poleemilises artiklis "Estonian word prosody on the Procrustean bed of morae". Esitatud loend vigadest sisaldab eesti keeleandmete väärtõlgendusi, vigaseid tsitaate ja kallutatud järeldusi.}

Märksõnad: strukturaal-funktsionaalne fonoloogia, autosegmentaalne fonoloogia, sõnaprosoodia, moora, välted, ülipikkus, eesti keel 